\section{Dement Geriatr Cogn Disord Extra 2012;2:19-28}

\begin{tabular}{l|l}
\hline DOI: $10.1159 / 000335775$ & ○ 2012 S. Karger AG, Basel
\end{tabular}

Published online: February 3, 2012

www.karger.com/dee

This is an Open Access article licensed under the terms of the Creative Commons AttributionNonCommercial-NoDerivs 3.0 License (www.karger.com/OA-license), applicable to the online version of the article only. Distribution for non-commercial purposes only.

Original Research Article

\title{
Factors Associated with a Depressive Disorder in Alzheimer's Disease Are Different from Those Found for Other Dementia Disorders
}

\author{
Maria Lage Barca ${ }^{a, b}$ d Knut Engedal $^{\mathrm{a}-\mathrm{c}}$ Jerson Laks ${ }^{\mathrm{d}}$ \\ Geir Selbaek ${ }^{a-c}$ \\ ${ }^{a}$ Norwegian Centre for Dementia Research, Centre for Ageing and Health, Department of \\ Geriatric Medicine, Oslo University Hospital, Ullevål, b ${ }^{b}$ Faculty of Medicine, University of \\ Oslo, Oslo, and ${ }^{\mathrm{C}}$ Research Centre for Old Age Psychiatric Research, Innlandet Hospital

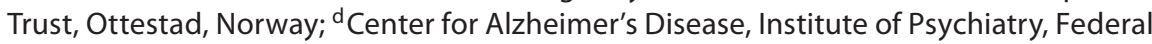 \\ University of Rio de Janeiro, Rio de Janeiro, Brazil
}

\section{Key Words}

Depression $\cdot$ Dementia $\cdot$ Alzheimer's disease $\cdot$ Inpatients $\cdot$ Institutions

\begin{abstract}
Background: This study explores factors associated with depression in Alzheimer's disease (AD) compared with mild cognitive impairment $(\mathrm{MCl})$ and other dementia disorders. Method: In a prospective study we included 195 patients: 31 with $\mathrm{MCl}, 112$ with $\mathrm{AD}$ and 52 with other dementias. Results: According to the ICD-10 and the DSM-IV criteria, 88 (44.1\%) and 59 (30.3\%), respectively, had a depressive disorder. An adjusted multiple regression analysis showed that previous depression $(p<0.05)$ was significantly associated with depression in AD patients. Severity of dementia $(p<0.05)$ was significantly associated with a depressive disorder in a group of patients with frontotemporal dementia, vascular dementia, or dementia due to Lewy Body disease or Parkinson's disease. Conclusion: We found different factors associated with a depressive disorder in $\mathrm{AD}$ compared to those found for other dementia disorders.
\end{abstract}




\section{Introduction}

Depression is highly prevalent among persons with dementia of any degree and any type, and even in patients with mild cognitive impairment (MCI). Various studies and review papers report prevalence rates of $20-25 \%$ for a depressive disorder, and 40 or even $50 \%$ if patients with minor depression or 'significant symptoms of depression' are included [1-3]. Some studies report a higher prevalence rate in patients in an early phase of dementia $[4,5]$, whereas other studies report the opposite, i.e. a higher prevalence rate in severe dementia [6-8]. However, a recently published review paper reported that depression, both at disorder and symptom level was equally often observed whatever the severity of the dementia [1]. Thus, depression in patients with dementia and MCI most probably is a heterogeneous condition that can be caused by psychological as well as by various biological factors.

In an early stage of dementia or in MCI, depression could be due to the patient's awareness of the disease and insight into impaired cognitive function [9]. In this context it is possible that depression in dementia could also be linked to stress, but this hypothesis has never been confirmed $[10,11]$.

Depression in a late stage of dementia, by contrast, could be due to specific structural or biochemical changes in the brain [12]. The evidence for an association between serotonin depletion and depression in patients with dementia is poor. Post-mortem studies are few, and they report contradictory results, include only a small number of patients and are not conclusive [13-15]. Studies with functional neuroimaging demonstrate, however, serotonergic dysfunction both in patients with Alzheimer's disease (AD) and frontotemporal lobar degeneration, also called frontotemporal dementia (FTD), but the location of the serotonergic dysfunction in the brain varies in different studies, and therefore it is difficult to draw significant conclusions [16]. Depression in dementia has also been found to be associated with decreased blood flow in the prefrontal areas, the superior frontal and anterior cingulate region, as demonstrated in two studies using the positron emission tomography technique $[17,18]$.

Another possible association between depression and dementia could be due to vascular changes of the brain as depression is more often seen in vascular dementia $(\mathrm{VaD})$ than in $\mathrm{AD}$ $[19,20]$. In addition, several studies have shown a significant relationship between vascular risk factors and depression in the elderly both with and without dementia [10, 21]. Depression could also be caused by specific structural damage, for example to the amygdala [22], in the frontal cortex or in the frontostriatal areas. As assessed by MRI, white matter hyperintensities in the frontal and right parietal lobe are correlated with depression in $\mathrm{AD}$ [23-25], but depression is even more prevalent in dementias where frontostriatal changes are common such as in FTD, dementia with Lewy bodies (DLB), Parkinson's disease dementia (PDD) and $\mathrm{VaD}[20,26]$.

A further explanation could be that genetic factors could increase the risk for depression in the course of a brain disorder, like $\mathrm{AD}$, stroke or Parkinson's disease. In a study by Holmes et al. [27], polymorphism of the receptor genes 5-HT2A and 5-HT2C were found to increase the risk of major depression in $\mathrm{AD}$ patients. A twelve-fold risk was found when individuals with homozygote 5-HT2C Ser allele were compared with individuals with the 5HT-2S Cys allele. In both AD and Parkinson's disease, alterations of the serotonin transporter gene were associated with depression, but not in $\mathrm{VaD}$ [28-30]. To sum up: it might be that a combination of awareness of and insight into cognitive impairment (a psychological factor), and biological factors together can increase the risk for depression. However, one has to bear in mind that significant risk factors for late depression in general, such as female gender and functional impairment [31], could also be important in cognitively impaired patients. 
Many elderly persons have depressive symptoms. In population-based studies it is reported that $11-30 \%$ have symptoms of depression, but this does not mean all these persons have a depressive disorder [32]. The same is found in clinical studies, where the prevalence rates are even higher [2].

Thus, the aim of the present study was to explore factors associated with a depressive disorder in patients with different types of dementia, especially to compare patients with AD and dementia disorders with a high probability of having suffered damage in the frontostriatal cortical circuit.

\section{Methods}

\section{Study Subjects}

We conducted the study between October 2008 and August 2009. The study population comprised 195 inpatients older than 60 years, with MCI and dementia of any type and of various degrees. They were recruited from two hospital departments of geriatric psychiatry $(n=94)$, one department of geriatric medicine $(n=10)$ and five nursing homes $(n=91)$. The patients from hospital departments of geriatric psychiatry were admitted for assessment for behavioral and psychiatric symptoms of dementia, and they were consecutively recruited for the study, whereas the patients in nursing homes and in the department of geriatrics were asked to participate without using any selection criteria. All patients had been staying in the institution for at least 4 weeks and many of the patients of the hospital sample had been admitted from nursing home care and were re-admitted to nursing home care after the assessments had been made in the hospital. The only exclusion criteria were patients with bipolar depression or manic episodes. A detailed description of the sample is given elsewhere [33].

\section{Diagnostic Procedures for the Diagnosis of Depression and Dementia}

The patients were interviewed by one of four senior geriatric psychiatrists, who had access to the patients' medical records. In cases of dementia of severe degree and/or aphasia, a nurse or a relative who knew the patient well was also interviewed. The psychiatrists diagnosed depression according to the research criteria of ICD-10 and DSM-IV (major depression). A template with a list of all the symptoms required for the two diagnoses of depression was used during the interview. The four psychiatrists met to ensure that the diagnostic procedures were followed in the same way.

The diagnosis of dementia was made after a comprehensive clinical examination according to the ICD-10 criteria for research. We used the ICD-10 to diagnose AD, VaD and PDD, whereas the Manchester-Lund criteria were used for the diagnosis of FTD and the revised McKeith criteria for the diagnosis of DLB [34, 35]. MCI was diagnosed according to the criteria by Winblad et al. [36]. The diagnostic assessment included the patient's medical history told by him-/herself and an informant, physical and mental examinations, laboratory tests, neuropsychological tests, and usually an image of the brain. In most cases, a dementia diagnostic investigation had been performed years before the present study and we used both the information from the patients' records and the information from the new clinical examination to make the dementia diagnosis.

\section{Assessment Scales}

The patients were assessed by seven trained research nurses, who applied three assessment scales. Prior to the present study they had received a 1-day training course and they could contact the project leader during the study if necessary. The Cornell Scale for Depres- 
sion in Dementia was used to rate depressive symptoms and a standard procedure was followed: a nurse filled in the scale after an interview with the patient's primary caregiver and a brief interview with the patient. The scale consists of 19 items. Each item is rated from 0 (no symptom) to 2 (severe symptom) (range $=0-38$ ). The scale allows for the entry, 'not possible to evaluate' [37]. The patient's ability to perform the basic activities of daily living was measured by interviewing the patients' primary caregivers by means of the Self Maintenance Scale [38]. It consists of 6 items and the score can vary between 6 and 30; a higher score denotes greater impairment.

Assessment of cognition and stage of dementia was done by the psychiatrists who made the diagnoses by means of the Mini Mental State Examination (MMSE) [39] and the Clinical Dementia Rating scale (CDR) [40]. The score on MMSE varies between 0 and 30; a higher score denotes better cognition. A score on CDR below 1 indicates no dementia, 1 indicates mild and 2 moderate dementia, whereas 3 denotes a severe degree of dementia. The CDR can also be used as a continuous scale by adding the individual item scores into a sum score. In that case, the minimum score is 0 and the maximum 18. No cutoff point is used with this method, but statistical analysis using the continuous CDR might have more statistical power. The two scoring systems correlate highly, about $0.9[41,42]$.

The patients' age, gender, previous and present medical and psychiatric history and their use of any drugs were collected from the patients' records. In addition and according to the case record form, the psychiatrists specifically interviewed a caregiver if the patients had suffered a depressive or any other psychiatric disorder earlier in life. Chronic and present physical disorders were organized in 10 groups of disorders, e.g. cardiovascular disorders, endocrine disorders, neoplasm, disorders in the eyes, ears, genitourinary organs, respiratory organs, digestive organs and also musculoskeletal disorders, and others.

\section{Statistics}

Statistical analyses were performed with SPSS version 17. For data on continuous scales we used the independent $t$ test to examine differences between groups (depressed vs. nondepressed) if the data was normally distributed, and the Mann-Whitney U test was used for non-normally distributed data. For categorical data, differences between groups were tested with the $\chi^{2}$ test in large groups and the Fisher exact test for smaller samples. Thereafter, we performed multiple logistic regression analyses (enter method) with a diagnosis of depression according to ICD-10 as the dependent variable. Variables with a p value below 0.2 in the simple comparative analyses in addition to age and gender were used as independent variables. We repeated the analyses with the DSM-IV diagnosis of depression as the dependent variable.

In the analyses we divided the 195 patients into four diagnostic groups: MCI, AD, unspecified dementia and a mixed diagnostic group consisting of patients with $\mathrm{VaD}, \mathrm{FTD}$, or $\mathrm{DLB} / \mathrm{PDD}$. The composition of the latter group was based on the assumption that changes in the frontostriatal circuit are associated with depression and that the reason for this might be structural brain changes. Due to a low number of patients, we decided to leave this as a mixed group.

\section{Ethics}

The study was approved by the Regional Ethics Committee, the Data Inspectorate and the Directorate for Health and Social Affairs. The patients gave their informed consent in writing. In cases where the patients had reduced or no capacity to give consent, the next of kin gave their informed consent in writing. 
Table 1. Characteristics of the 195 patients

\begin{tabular}{|c|c|}
\hline Women & $132(67.7)$ \\
\hline Age, years & $82 \pm 7.8$ \\
\hline Married & $72(36.9)$ \\
\hline MMSE score & $12.9 \pm 8.8$ \\
\hline \multicolumn{2}{|l|}{ CDR } \\
\hline 0.5 & $22(11.3)$ \\
\hline 1.0 & $38(19.5)$ \\
\hline 2.0 & $53(27.2)$ \\
\hline 3.0 & $81(41.5)$ \\
\hline Previous depression & $51(26.2)$ \\
\hline Cornell score & $9.0 \pm 5.5$ \\
\hline PADL score & $16.4 \pm 5.9$ \\
\hline Physical disorders ${ }^{\mathrm{a}}$ & $2.8 \pm 1.7$ \\
\hline ICD-10 depressive disorder & $86(44.1)$ \\
\hline Use of antidepressants, non-depressed & $37 / 109(33.9)$ \\
\hline Use of antidepressants, depressed & $61 / 86(70.9)$ \\
\hline
\end{tabular}

Figures are $\mathrm{n}(\%)$ or means \pm SD.

a Physical disorders were grouped into 10 subgroups, see text.

Table 2. Prevalence rates of a depressive disorder for the 4 diagnostic groups according to the ICD-10 criteria and DSM-IV criteria for major depression

\begin{tabular}{lrr}
\hline Diagnosis & ICD-10 criteria, $\mathrm{n}(\%)$ & DSM-IV criteria, $\mathrm{n}(\%)$ \\
\hline MCI $(\mathrm{n}=31)$ & $9(29.0)$ & $5(16.1)$ \\
$\mathrm{AD}(\mathrm{n}=112)$ & $53(47.3)$ & $39(34.8)$ \\
Other defined dementias $(\mathrm{n}=31)^{\mathrm{a}}$ & $16(52.0)$ & $11(35.5)$ \\
Mixed or unspecified dementia $(\mathrm{n}=21)$ & $8(38.1)$ & $4(19.0)$ \\
\hline
\end{tabular}

${ }^{\mathrm{a}} \mathrm{VaD}=20, \mathrm{DLB} / \mathrm{PDD}=6, \mathrm{FTD}=5$.

\section{Results}

Of the 195 patients, 31 (15.9\%) had MCI, 112 (57.5\%) had AD, 20 (10.3\%) had VaD, 6 (3.1\%) had DLB or PDD, 5 (2.6\%) had FTD, and 21 (10.8\%) had atypical or unspecified dementia. Table 1 shows the patient characteristics for the 195 patients, including the use of antidepressants. Among the 195 patients with MCI or dementia, 86 (44.1\%) had depression according to ICD-10: 31 (15.9\%) mild, 37 (19\%) moderate, and 18 (9.2\%) severe; and 59 (30.3\%) had major depression according to DSM-IV criteria. Among the 112 patients with AD, 53 (47.3\%) had depression according to ICD-10: 19 (17\%) mild, 24 (21.4\%) moderate, and 10 (8.9\%) severe; and 39 (34.8\%) had major depression according to DSM-IV criteria. All patients with a DSM-IV major depression were also diagnosed as depressed using the ICD-10 criteria. Table 2 shows the prevalence rate of depression according to MCI and dementia diagnoses.

Table 3 shows differences between the depressed and non-depressed groups in each of the four diagnostic groups using the ICD-10 criteria for the diagnosis of depression. We also tested differences for the presence of the 10 most prevalent physical disorders, but none of these differed between the depressed and non-depressed patients in the four groups (data not shown). We also tested for differences between the depressed and non-depressed subjects for 
Table 3. Comparison of characteristics between patients with and without depression according to ICD-10

\begin{tabular}{|c|c|c|c|c|c|c|c|c|c|c|c|c|}
\hline \multirow[t]{2}{*}{ Characteristic } & \multicolumn{3}{|l|}{$\begin{array}{l}\mathrm{AD} \\
(\mathrm{n}=112)\end{array}$} & \multicolumn{3}{|c|}{$\begin{array}{l}\mathrm{VaD} / \mathrm{DLB} / \mathrm{PDD} / \mathrm{FTD} \\
(\mathrm{n}=31)\end{array}$} & \multicolumn{3}{|l|}{$\begin{array}{l}\text { MCI } \\
(\mathrm{n}=31)\end{array}$} & \multicolumn{3}{|c|}{$\begin{array}{l}\text { Unspecified dementia } \\
(\mathrm{n}=21)\end{array}$} \\
\hline & $\begin{array}{l}\text { depressed } \\
(\mathrm{n}=53)\end{array}$ & $\begin{array}{l}\text { non-de- } \\
\text { pressed } \\
(\mathrm{n}=59)\end{array}$ & $\begin{array}{l}\mathrm{p} \text { value } \\
\text { t test or } \chi^{2}\end{array}$ & $\begin{array}{l}\text { depressed } \\
(\mathrm{n}=16)\end{array}$ & $\begin{array}{l}\text { non-de- } \\
\text { pressed } \\
(\mathrm{n}=15)\end{array}$ & $\begin{array}{l}\mathrm{p} \text { value } \\
\mathrm{t} \text { test or } \\
\text { Fisher }\end{array}$ & $\begin{array}{l}\text { depressed } \\
(\mathrm{n}=9)\end{array}$ & $\begin{array}{l}\text { non-de- } \\
\text { pressed } \\
(\mathrm{n}=22)\end{array}$ & $\begin{array}{l}\mathrm{p} \text { value } \\
\mathrm{t} \text { test or } \\
\text { Fisher }\end{array}$ & $\begin{array}{l}\text { depressed } \\
(\mathrm{n}=8)\end{array}$ & $\begin{array}{l}\text { non-de- } \\
\text { pressed } \\
(\mathrm{n}=13)\end{array}$ & $\begin{array}{l}\mathrm{p} \text { value } \\
\mathrm{t} \text { test or } \\
\text { Fisher }\end{array}$ \\
\hline Age, years & $82.0 \pm 8.1$ & $83.9 \pm 7.7$ & 0.20 & $80.0 \pm 87.3$ & $79.9 \pm 8.6$ & 0.95 & $77.6 \pm 6.8$ & $79.9 \pm 7.5$ & 0.42 & $84.3 \pm 7.1$ & $83.7 \pm 5.9$ & 0.85 \\
\hline Women & $40(75.5)$ & $37(62.7)$ & 0.15 & $7(43.8)$ & $8(53.3)$ & 0.58 & $6(66.7)$ & $17(77.3)$ & 0.66 & $7(87.5)$ & $10(76.9)$ & 1.00 \\
\hline Married & $15(28.3)$ & $20(33.9)$ & 0.52 & $7(43.8)$ & $6(40)$ & 0.83 & $6(66.7)$ & $9(40.9)$ & 0.25 & $6(75)$ & $3(23.1)$ & 0.03 \\
\hline CDR sum & $13.5 \pm 4.1$ & $13.5 \pm 3.9$ & 1.00 & $12.8 \pm 4.1$ & $9.0 \pm 4.5$ & 0.03 & $5.8 \pm 42.0$ & $4.7 \pm 3.7$ & 0.52 & $11.3 \pm 7.0$ & $11.0 \pm 4.8$ & 0.91 \\
\hline PSMS score & $16.7 \pm 5.5$ & $17.7 \pm 5.1$ & 0.31 & $19.1 \pm 5.5$ & $15.8 \pm 5.5$ & 0.12 & $12.3 \pm 5.3$ & $11.0 \pm 4.0$ & 0.48 & $15.3 \pm 8.5$ & $17.8 \pm 7.3$ & 0.47 \\
\hline Physical disorders & $3.0 \pm 2.0$ & $2.7 \pm 1.6$ & 0.35 & $2.8 \pm 1.5$ & $3.3 \pm 1.7$ & 0.44 & $3.2 \pm 1.1$ & $2.6 \pm 1.4$ & 0.27 & $2.5 \pm 1.6$ & $2.7 \pm 2.2$ & 0.83 \\
\hline
\end{tabular}

Figures are $\mathrm{n}(\%)$ or means \pm SD. PSMS = Physical Self Maintenance Scale.

Table 4. Multiple logistic regression of correlates of depression according to ICD-10 and DSM-IV among patients with MCI and dementia

\begin{tabular}{|c|c|c|c|c|c|c|c|c|}
\hline & \multicolumn{4}{|c|}{ ICD-10 criteria } & \multicolumn{4}{|c|}{ DSM-IV criteria } \\
\hline & $\mathrm{B}$ & Wald & OR (95\% CI) & $\mathrm{p}$ value & B & Wald & OR (95\% CI) & $\mathrm{p}$ value \\
\hline \multicolumn{9}{|l|}{ All $(n=195)$} \\
\hline Previous depression & 1.09 & 9.16 & $3.0(1.5-6.1)$ & 0.002 & 1.26 & 10.81 & $3.5(1.7-7.5)$ & 0.001 \\
\hline CDR score & 0.76 & 5.9 & $1.1(1.0-1.15)$ & 0.02 & 0.11 & 8.88 & $1.1(1.03-1.2)$ & 0.03 \\
\hline Age $<85$ versus $\geq 85$ & 0.30 & 0.93 & $0.74(0.4-1.4)$ & 0.34 & 0.91 & 6.2 & $0.41(0.2-0.8)$ & 0.01 \\
\hline \multicolumn{9}{|l|}{$M C I(n=31)$} \\
\hline Previous depression & 2.22 & 4.17 & $9.2(1.1-77.7)$ & 0.04 & 2.39 & 3.02 & $10.9(0.7-161)$ & 0.08 \\
\hline CDR score & 0.01 & 0.01 & $0.99(0.8-1.2)$ & 0.92 & 0.00 & 0.00 & $0.99(0.8-1.3)$ & 0.99 \\
\hline \multicolumn{9}{|l|}{$A D(n=112)$} \\
\hline Previous depression & 1.02 & 4.47 & $2.8(1.1-7.1)$ & 0.034 & 1.42 & 8.07 & $4.1(1.6-10.9)$ & 0.005 \\
\hline CDR score & 0.02 & 0.16 & $1.0(0.9-1.1)$ & 0.69 & 0.41 & 0.53 & $1.04(0.9-1.7)$ & 0.46 \\
\hline Age $<85$ versus $\geq 85$ & 0.43 & 1.15 & $0.65(0.29-1.4)$ & 0.28 & -1.0 & 4.93 & $0.37(0.15-0.9)$ & 0.03 \\
\hline \multicolumn{9}{|l|}{$V a D / F T D / D L B P D D(n=31)$} \\
\hline Previous depression & 1.79 & 1.70 & $6.0(0.4-89.0)$ & 0.20 & 1.32 & 1.18 & $3.7(0.3-41)$ & 0.28 \\
\hline CDR score & 0.21 & 4.38 & $1.2(1.01-1.5)$ & 0.04 & 0.25 & 4.81 & $1.3(1.03-1.6)$ & 0.03 \\
\hline \multicolumn{9}{|l|}{ Unspecified dementia $(n=21)$} \\
\hline Previous depression & 0.90 & 0.94 & $2.5(0.4-15.1)$ & 0.33 & 1.0 & 0.93 & $4.3(0.22-85)$ & 0.33 \\
\hline CDR score & 0.63 & 0.25 & $1.1(0.8-1.4)$ & 0.62 & 0.34 & 0.51 & $1.03(0.8-1.4)$ & 0.82 \\
\hline
\end{tabular}

Hosmer-Lemeshow test above 0.05 in all models.

the whole group of the mentally impaired 195 patients, regardless of diagnoses, and found that younger age of patients $\left(\chi^{2}\right.$ test, $\left.p=0.04\right)$, a history of depression $\left(\chi^{2}\right.$ test, $\left.p<0.001\right)$ and the presence of a genitourinary disorder $\left(\chi^{2}\right.$ test, $\left.\mathrm{p}=0.04\right)$ were associated with depression. The results using the DSM-IV diagnosis of depression did not differ from this result (not shown).

Table 4 shows the results of 10 multiple logistic regression analyses. For all patients $(\mathrm{n}=$ 195) both a history of depression and the severity of dementia was significantly associated with a depressive disorder according to ICD-10, and when using the DSM-IV criteria, younger age was also a significant factor. As can be observed in table 4, we found different risk fac- 
tor profiles for depression in patients with $\mathrm{AD}$ and the mixed group with the diagnoses of $\mathrm{VaD} / \mathrm{FTD} / \mathrm{DLB} / \mathrm{PDD}$, both by the use of ICD-10 and DSM-IV criteria. A history of depression was significantly associated with a depressive disorder in $\mathrm{AD}$, whereas the severity of dementia as measured by the CDR was not significant. For the group of patients with $\mathrm{VaD} /$ $\mathrm{FTD} / \mathrm{DLB} / \mathrm{PDD}$ the results were the other way round. The results for the $\mathrm{MCI}$ patients were similar to the $\mathrm{AD}$ patients, whereas for the patients with atypical or unspecified dementia, we found no factor associated with a depressive disorder. Gender or any physical disorders or functional impairment were not statistically significant in any of the models.

\section{Discussion}

The two main findings of the present study were that a history of (previous) depression was the strongest factor associated with a depressive disorder in the AD patients regardless of whether we used the ICD-10 criteria for depression, which is less strict, or the DSM-IV criteria. The strongest factor associated with a depressive disorder in the group of patients with possible damage to the frontostriatal circuit was severity of dementia. These results could indicate that psychological factors such as awareness and insight into their own cognitive impairment is among the most important risk factors for a depressive disorder in AD patients. However, as we have no information on the patients' awareness, we cannot know for sure. One could argue that this interpretation is partly supported by the fact that a history of depression was also significantly associated with a depressive disorder among the MCI patients (using the ICD-10 criteria for depression). We cannot claim that genetic factors play a role, as we have not done any genetic testing. However, it is possible that individuals with a genetic predisposition for depression are more at risk of developing depression in stressful situations throughout life $[11,43]$. To suffer from MCI and dementia is without doubt such a stressful event.

Using the DSM-IV criteria for a depressive disorder, younger age was significantly associated with a depressive disorder, a finding that is supported by several other studies showing that depression is more common among younger than among elderly patients with dementia [44].

Severity of dementia was associated with depressive disorder in the mixed group of $\mathrm{VaD} /$ FTD/DLB/PDD patients. We suggest that psychological factors cannot explain this association, because a history of depression was not a significant factor in these patients. On the contrary, biological factors are probably the explanation. We hypothesize that structural changes in the frontostriatal areas might be the main cause for depression in this group. A change in the frontostriatal circuit has been shown to be associated with depression in other studies as well [24].

As seen in table 3, many of the patients without a depressive disorder received antidepressants and some of those with a depressive disorder did not receive drug treatment. Could the prescription and use of antidepressants have influenced the results? Could it be that some of the users of antidepressants had recently recovered from depression? We do not know, and the question remains open. The explanation for the widespread use of antidepressants among Norwegian patients with dementia may be a result of the custom among doctors to prescribe antidepressants for the treatment of neuropsychiatric symptoms. Several large studies have shown that $35-40 \%$ of all nursing home patients receive antidepressants $[45,46]$.

The study has limitations. First, we included patients from three sources, which could have biased the results. A typical nursing home patient may be different from a patient admitted to a hospital for assessment and treatment. However, most of the in-hospital patients either came from a nursing home or were admitted to a nursing home after treatment. We 
do not have the exact number, but in another paper we have shown that they do not differ. Second, although the four psychiatrists were specially trained in geriatric psychiatry they could have diagnosed depression differently. One could argue that at least two psychiatrists should have diagnosed all the patients. For practical reasons this was not possible, but to ensure that the psychiatrists used the same diagnostic procedure a common template was used, and the psychiatrists discussed the diagnostic process during the study. Third, the etiological diagnosis of dementia is difficult to make. We used standard research criteria for the different diagnoses and compared previous and present findings from dementia work-ups but still it could be difficult to obtain the correct dementia diagnosis. An fourth limitation is the small number of patients, which could influence the statistical analyses. The logistic regression models included a small number of patients in some of the diagnostic groups which resulted in large 95\% confidence intervals for the odds ratios. However, the Hosmer-Lemeshow test was above 0.05 for all analyses, supporting the models. But, the confidence intervals were narrow regarding the results of the main findings, the analyses of the factors significantly associated with a depressive disorder in the AD and the VaD/FTD/DLB/PDD patients (table 4).

We conclude that a history of depression was the strongest significant factor associated with a depressive disorder in AD and that severity of dementia was the strongest factor associated with depression in the group of patients with either a diagnosis of VaD, FTD, or DLB.

\section{Acknowledgement}

The authors would like to thank the Norwegian National Health Association and the Conselho Nacional de Pesquisa (Brazilian National Council for Research) for support.

\section{Disclosure Statement}

M.L. Barca, K. Engedal and J. Laks: none.

G. Selbæk has given presentations at conferences sponsored by Novartis and Lundbeck.

\section{References}

-1 Verkaik R, Nuyen J, Schellevis F, Francke A: The relationship between severity of Alzheimer's disease and prevalence of comorbid depressive symptoms and depression: a systematic review. Int J Geriatr Psychiatry 2007;22:1063-1086.

-2 Selbaek G, Kirkevold O, Engedal K: The prevalence of psychiatric symptoms and behavioural disturbances and the use of psychotropic drugs in Norwegian nursing homes. Int J Geriatr Psychiatry 2007; 22:843-849.

-3 Lyketsos CG, Olin J: Depression in Alzheimer's disease: overview and treatment. Biol Psychiatry 2002;52:243-252.

-4 Burns A, Jacoby R, Levy R: Psychiatric phenomena in Alzheimer's disease. III: disorders of mood. Br J Psychiatry 1990;157:81-86, 92-94.

-5 Lyketsos CG, Steinberg M, Tschanz JT, Norton MC, Steffens DC, Breitner JC: Mental and behavioral disturbances in dementia: findings from the Cache County Study on Memory in Aging. Am J Psychiatry 2000;157:708-714.

-6 Piccininni M, Di Carlo A, Baldereschi M, Zaccara G, Inzitari D: Behavioral and psychological symptoms in Alzheimer's disease: frequency and relationship with duration and severity of the disease. Dement Geriatr Cogn Disord 2005;19:276-281. 
-7 Starkstein SE, Jorge R, Mizrahi R, Robinson RG: The construct of minor and major depression in Alzheimer's disease. Am J Psychiatry 2005;162:2086-2093.

-8 Barca ML, Selbaek G, Laks J, Engedal K: Factors associated with depression in Norwegian nursing homes. Int J Geriatr Psychiatry 2009;24:417-425.

-9 Harwood DG, Sultzer DL, Wheatley MV: Impaired insight in Alzheimer disease: association with cognitive deficits, psychiatric symptoms, and behavioral disturbances. Neuropsychiatry Neuropsychol Behav Neurol 2000;13:83-88.

-10 Teper E, O'Brien JT: Vascular factors and depression. Int J Geriatr Psychiatry 2008;23:993-1000.

-11 Beck AT: The evolution of the cognitive model of depression and its neurobiological correlates. Am J Psychiatry 2008;165:969-977.

-12 Steffens DC, Potter GG: Geriatric depression and cognitive impairment. Psychol Med 2008;38:163175 .

-13 Sharp SI, Ballard CG, Ziabreva I, Piggott MA, Perry RH, Perry EK, Aarsland D, Ehrt U, Larsen JP, Francis PT: Cortical serotonin la receptor levels are associated with depression in patients with dementia with Lewy bodies and Parkinson's disease dementia. Dement Geriatr Cogn Disord 2008;26: $330-338$.

-14 Forstl H, Burns A, Luthert P, Cairns N, Lantos P, Levy R: Clinical and neuropathological correlates of depression in Alzheimer's disease. Psychol Med 1992;22:877-884.

-15 Hendricksen M, Thomas AJ, Ferrier IN, Ince P, O'Brien JT: Neuropathological study of the dorsal raphe nuclei in late-life depression and Alzheimer's disease with and without depression. Am J Psychiatry 2004;161:1096-1102.

-16 Salmon E: A review of the literature on neuroimaging of serotoninergic function in Alzheimer's disease and related disorders. J Neural Transm 2007;114:1179-1185.

-17 Hirono N, Mori E, Ishii K, Ikejiri Y, Imamura T, Shimomura T, Hashimoto M, Yamashita H, Sasaki M: Frontal lobe hypometabolism and depression in Alzheimer's disease. Neurology 1998;50:380383.

-18 Holthoff VA, Beuthien-Baumann B, Kalbe E, Ludecke S, Lenz O, Zundorf G, Spirling S, Schierz K, Winiecki P, Sorbi S, Herholz K: Regional cerebral metabolism in early Alzheimer's disease with clinically significant apathy or depression. Biol Psychiatry 2005;57:412-421.

-19 Park JH, Lee SB, Lee TJ, Lee DY, Jhoo JH, Youn JC, Choo IH, Choi EA, Jeong JW, Choe JY, Woo JI, Kim KW: Depression in vascular dementia is quantitatively and qualitatively different from depression in Alzheimer's disease. Dement Geriatr Cogn Disord 2007;23:67-73.

-20 Ballard C, Neill D, O’Brien J, McKeith IG, Ince P, Perry R: Anxiety, depression and psychosis in vascular dementia: prevalence and associations. J Affect Disord 2000;59:97-106.

-21 Almeida OP, Flicker L, Norman P, Hankey GJ, Vasikaran S, van Bockxmeer FM, Jamrozik K: Association of cardiovascular risk factors and disease with depression in later life. Am J Geriatr Psychiatry 2007;15:506-513.

-22 Lopez OL, Becker JT, Sweet RA, Martin-Sanchez FJ, Hamilton RL: Lewy bodies in the amygdala increase risk for major depression in subjects with Alzheimer disease. Neurology 2006;67:660-665.

- 23 O'Brien J, Desmond P, Ames D, Schweitzer I, Harrigan S, Tress B: A magnetic resonance imaging study of white matter lesions in depression and Alzheimer's disease. Br J Psychiatry 1996;168:477485.

24 Malloy P, Correia S, Stebbins G, Laidlaw DH: Neuroimaging of white matter in aging and dementia. Clin Neuropsychol 2007;21:73-109.

- 25 Starkstein SE, Mizrahi R, Capizzano AA, Acion L, Brockman S, Power BD: Neuroimaging correlates of apathy and depression in Alzheimer's disease. J Neuropsychiatry Clin Neurosci 2009;21:259-265.

-26 Borroni B, Agosti C, Padovani A: Behavioral and psychological symptoms in dementia with Lewybodies (DLB): frequency and relationship with disease severity and motor impairment. Arch Gerontol Geriatr 2008;46:101-106.

27 Holmes C, Arranz M, Collier D, Powell J, Lovestone S: Depression in Alzheimer's disease: the effect of serotonin receptor gene variation. Am J Med Genet B Neuropsychiatr Genet 2003;119B:40-43.

- 28 Mossner R, Henneberg A, Schmitt A, Syagailo YV, Grassle M, Hennig T, Simantov R, Gerlach M, Riederer P, Lesch KP: Allelic variation of serotonin transporter expression is associated with depression in Parkinson's disease. Mol Psychiatry 2001;6:350-352.

-29 Ouchi Y, Yoshikawa E, Futatsubashi M, Yagi S, Ueki T, Nakamura K: Altered brain serotonin transporter and associated glucose metabolism in Alzheimer disease. J Nucl Med 2009;50:1260-1266. 
-30 Seripa D, Matera MG, D’Onofrio G, Sancarlo D, Bizzarro A, Cascavilla L, Paris F, Gravina C, Bonghi L, Capurso C, Solfrizzi V, Daniele A, Masullo C, Panza F, Pilotto A: Polymorphism C in the serotonin transporter gene in depression-free elderly patients with vascular dementia. Dement Geriatr Cogn Disord 2010;29:424-431.

- 31 Cole MG, Dendukuri N: Risk factors for depression among elderly community subjects: A systematic review and meta-analysis. Am J Psychiatry 2003;160:1147-1156.

- 32 Copeland JR, Beekman AT, Dewey ME, Jordan A, Lawlor BA, Linden M, Lobo A, Magnusson H, Mann AH, Fichter M, Prince MJ, Saz P, Turrina C, Wilson KC: Cross-cultural comparison of depressive symptoms in Europe does not support stereotypes of ageing. Br J Psychiatry 1999;174:322-329.

-33 Barca ML, Engedal K, Selbaek G: A reliability and validity study of the Cornell scale among elderly inpatients, using various clinical criteria. Dement Geriatr Cogn Disord 2010;29:438-447.

-34 Neary D, Snowden JS, Gustafson L, Passant U, Stuss D, Black S, Freedman M, Kertesz A, Robert PH, Albert M, Boone K, Miller BL, Cummings J, Benson DF: Frontotemporal lobar degeneration: a consensus on clinical diagnostic criteria. Neurology 1998;51:1546-1554.

-35 McKeith IG, Dickson DW, Lowe J, Emre M, O’Brien JT, Feldman H, Cummings J, Duda JE, Lippa C, Perry EK, Aarsland D, Arai H, Ballard CG, Boeve B, Burn DJ, Costa D, Del Ser T, Dubois B, Galasko D, Gauthier S, Goetz CG, Gomez-Tortosa E, Halliday G, Hansen LA, Hardy J, Iwatsubo T, Kalaria RN, Kaufer D, Kenny RA, Korczyn A, Kosaka K, Lee VM, Lees A, Litvan I, Londos E, Lopez OL, Minoshima S, Mizuno Y, Molina JA, Mukaetova-Ladinska EB, Pasquier F, Perry RH, Schulz JB, Trojanowski JQ, Yamada M: Diagnosis and management of dementia with Lewy bodies: third report of the DLB consortium. Neurology 2005;65:1863-1872.

-36 Winblad B, Palmer K, Kivipelto M, Jelic V, Fratiglioni L, Wahlund LO, Nordberg A, Backman L, Albert M, Almkvist O, Arai H, Basun H, Blennow K, de Leon M, DeCarli C, Erkinjuntti T, Giacobini E, Graff C, Hardy J, Jack C, Jorm A, Ritchie K, van Duijn C, Visser P, Petersen RC: Mild cognitive impairment - beyond controversies, towards a consensus: report of the International Working Group on Mild Cognitive Impairment. J Intern Med 2004;256:240-246.

-37 Alexopoulos GS, Abrams RC, Young RC, Shamoian CA: Cornell scale for depression in dementia. Biol Psychiatry 1988;23:271-284.

- 38 Lawton MP, Brody EM: Assessment of older people: self-maintaining and instrumental activities of daily living. Gerontologist 1969;9:179-186.

- 39 Folstein MF, Folstein SE, McHugh PR: 'Mini-mental state'. A practical method for grading the cognitive state of patients for the clinician. J Psychiatr Res 1975;12:189-198.

-40 Hughes CP, Berg L, Danziger WL, Coben LA, Martin RL: A new clinical scale for the staging of dementia. Br J Psychiatry 1982;140:566-572.

-41 Barca ML, Selbaek G, Laks J, Engedal K: Factors associated with depression in Norwegian nursing homes. Int J Geriatr Psychiatry 2009;24:417-425.

-42 O’Bryant SE, Waring SC, Cullum CM, Hall J, Lacritz L, Massman PJ, Lupo PJ, Reisch JS, Doody R: Staging dementia using Clinical Dementia Rating Scale Sum of Boxes scores: a Texas Alzheimer's research consortium study. Arch Neurol 2008;65:1091-1095.

$\checkmark 43$ Fiocco AJ, Joober R, Poirier J, Lupien S: Polymorphism of the 5-HT(2A) receptor gene: association with stress-related indices in healthy middle-aged adults. Front Behav Neurosci 2007;1:3.

-44 Rosness TA, Barca ML, Engedal K: Occurrence of depression and its correlates in early onset dementia patients. Int J Geriatr Psychiatry 2010;25:704-711.

-45 Kirkevold O, Engedal K: Concealment of drugs in food and beverages in nursing homes: cross sectional study. BMJ 2005;330:20.

-46 Selbaek G, Kirkevold O, Engedal K: The course of psychiatric and behavioral symptoms and the use of psychotropic medication in patients with dementia in Norwegian nursing homes - a 12-month follow-up study. Am J Geriatr Psychiatry 2008;16:528-536. 